\title{
Investigation of the Photon to Charge Conversion and Its Implication on Photovoltaic Cell Efficient Operation
}

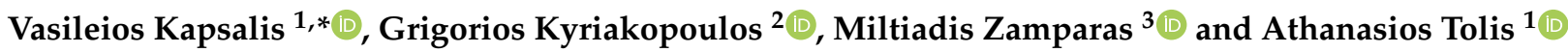 \\ 1 Sector of Industrial Management and Operational Research, School of Mechanical Engineering, \\ Zografou Campus, National Technical University of Athens, 15780 Athens, Greece; atol@central.ntua.gr \\ 2 Photometry Laboratory, Electric Power Division, School of Electrical and Computer Engineering, \\ Zografou Campus, National Technical University of Athens, 15780 Athens, Greece; \\ gregkyr@chemeng.ntua.gr \\ 3 School of Science and Technology, Hellenic Open University, Parodos Aristotelous 18, 26335 Patras, Greece; \\ mzamparas@upatras.gr \\ * Correspondence: bkapsal@mail.ntua.gr
}

check for updates

Citation: Kapsalis, V.; Kyriakopoulos, G.; Zamparas, M.; Tolis, A. Investigation of the Photon to Charge Conversion and Its Implication on Photovoltaic Cell Efficient Operation. Energies 2021, 14 3022. https://doi.org/10.3390/ en14113022

Academic Editors: Goodarz Ahmadi, Kiao Inthavong and Pouyan Talebizadeh Sardari

Received: 14 April 2021

Accepted: 18 May 2021

Published: 23 May 2021

Publisher's Note: MDPI stays neutral with regard to jurisdictional claims in published maps and institutional affiliations.

Copyright: (C) 2021 by the authors Licensee MDPI, Basel, Switzerland. This article is an open access article distributed under the terms and conditions of the Creative Commons Attribution (CC BY) license (https:// creativecommons.org/licenses/by/ $4.0 /)$

\begin{abstract}
Efficient photon to charge (PTC) transfer is considered to be the cornerstone of technological improvements in the photovoltaic (PV) industry, while it constitutes the most common process in nature. This study aims to investigate the parameters that impact efficient PV-cell photon to charge conversion in two ways: (a) providing a brief research analysis to extract the key features which affect the electrical and optical performance of PV cells' operation, and (b) investigating the dependance of these characteristics on the photon to charge mechanisms. The former direction focuses on the latest advances regarding the impacts of the microenvironment climate conditions on the PV module and its operational performance, while the latter examines the fundamental determinants of the cell's efficient operation. The electrical and optical parameters of the bulk PV cells are influenced by both the external microenvironment and the intrinsic photon to charge conversion principles. Light and energy harvesting issues need to be overcome, while nature-inspired interpretation and mimicking of photon to charge and excitation energy transfer are in an infant stage, furthering a better understanding of artificial photosynthesis. A future research orientation is proposed which focuses on scaling up development and making use of the before mentioned challenges.
\end{abstract}

Keywords: photovoltaic cell efficiency; thermal regulation; energy and light harvesting; irreversibility losses; quantum dynamics; nature-inspired mimicking

\section{Introduction}

Nowadays, carbon footprint awareness and the necessity of environmental protection have become significant issues in our daily activities. These considerations affect the decisions we make on energy sources and use of alternatives, as well as technological production and consumption patterns, leading to major economic and social consequences. Many efforts are being conducted to model and design efficient carbon emission systems in all industrial sectors, such as metallurgy, construction, shipping, manufacturing, transportation, to name some [1-6]. In most cases, efficient processes go together with an efficient transition to a low carbon economy, however, we have to admit that there are always cases with contradicting and competitive interactions which are worthy of investigation. In this research work, our concern refers to PV systems in order to get a deeper insight into the role of efficiency in operational mode.

Solar photovoltaic (PV) systems that directly convert sunlight into electricity are small scale and highly modular devices. They offer efficient resilience, flexibility, and adaptation to the grid energy supply. They have often been considered as the ideal distributed electricity production since they are derived from solar energy, which is a ubiquitous, inexhaustible, and renewable form of energy and is widely exploited in our society. In 
recent years, the value of integrated grid-connected PVs has been recognized around the world and many programs have been carried out in many countries to enhance architectural and technical quality in the built environment, storage potential, and the removal of economic and non-technical barriers in order introduce PVs as an energy-significant resource. Energy market reforms and the concept of decentralized energy systems drove research into different hybrid systems with a combined effect on energy production and consumption, therefore, analyzing both demand and supply-side management. The intensive research orientation toward efficiency [7-9] produced the proposal that every house could act as a net energy positive provider, taking into account combined utilizations to increase the benefits of outputs [10]. Electricity production is the main driving force for the installation of integrated PV systems, but, in recent years, installations have also been recognized which establish combined electricity and thermal energy, such as coupled photovoltaic-thermal collectors to enhance heating and cooling demand coverage, to act as refrigerator alternatives [11], or to increase thermal energy storage [12], while there are many reports of the application of standalone PV systems to solar power pumps in irrigation, livestock watering, and solar-powered water purification $[13,14]$. The entry of these renewable systems to the grid can also affect buildings' energy demand mixture, providing effective management of short-term buffering options in alignment with battery storage $[15,16]$. Many concerns regarding more efficient ways to implement energy and environmental systems lead to exploring hybrid combinations in order to optimize the path for a low carbon transition towards these systems. Renewable energy sources penetration into the grid-connected power technologies bring new contradicting issues, including the cost of the mismatch between demand and supply and intermittent and unpredictable availability [17], although in many studies they are viewed as a net provider due to the cumulative declining production costs [18-20]. In any case, increased renewable penetration, rational exergy management models, and reduced interaction with the utility grid are of paramount importance and delignate a robust pathway for $\mathrm{CO}_{2}$ mitigation from the built environment [21], as well as effective management of grid parity [22]. Typically, a PV system depends on cell performance which in turn depends on different mechanisms regarding complex design, fabrication, and operation parameters.

Therefore, investigation of the efficient operation of PV cell electricity output is a matter of continuous interest. This study investigates the PV efficient cell operation from both sides, namely the incoming microenvironmental conditions and the exploitation of the fundamental mechanisms of PTC transition, which affect the solar cell efficient operation. The rest of the paper is organized as follows: in Section 2 the critical parameters are derived under a brief literature review on the microenvironment determinants on PV efficient operation and output. Section 3, following an analysis on PV fundamental concepts, proceeds with a deeper insight on the different technologies of solar cells. In particular, the mechanisms of the photon to energy conversion are explored in terms of design, fabrication, and materials. In Section 4 the results are analyzed and a discussion is developed. The main findings with a proposed future research orientation are concluded in Section 5.

\section{Materials and Methods}

Many efforts have been made in the field of the cooling effect of photovoltaic cells [23], increasing efficiency by reducing the cell temperature [24] or expanding thermal regulation time during the charging and discharging process in sensible, latent, or thermochemical storage mechanisms [12,25-32]. A review on PV cooling technologies regarding the three-heat transfer mechanism (convection, conduction, and radiation) can be found in literature [33]. The optimization of operating temperature increases in the lifetime of the system by decreasing the thermo-mechanical fatigue for typical failure mechanisms [34] and has a significant influence on PV efficiency output. The correlation between the examined PV cell temperature and the environmental independent variables is found by a regression analysis [34] and for fixed period measurements. The model was implemented 
at various periods within the year. Sensitivity analysis for different weather conditions was conducted for longer and seasonal periods. It was found that the coefficients of the above method have to be taken with care during other periods since they refer to a local solution. Indeed, different declined angles of the independent variables fitted different periods, however the regression model conserved its linearity over the whole year. It is of great importance that the PV array temperature is controlled because it has been found that the power output decreases about $0.5 \%$ for every degree of Celsius increase, depending on the environmental conditions [34]. Reduced cell temperature is associated with increased efficiency which in turn leads to reduced thermal stresses and degradation of the modules. Therefore, it is essential to prevent the cell from overheating. The fill factor $(F F)$ is considered as a measurement of exergy degradation of the $\mathrm{PV}$ at a maximum power point output $\left(P_{\max }\right.$ at $\left.m p p\right)$, as in Figure 1, and it is related to the voltage and current in that point $\left(V_{m p p}\right.$ and $\left.I_{m p p}\right)$, as well as the open circuit current voltage and the short circuit current values ( $V_{o c}$ and $I_{s c}$ correspondingly). It is derived from the following equation [35].

$$
F F=\frac{V_{m p p} I_{m p p}}{V_{o c} I_{s c}}=\frac{P_{m a x}}{V_{o c} I_{s c}}
$$

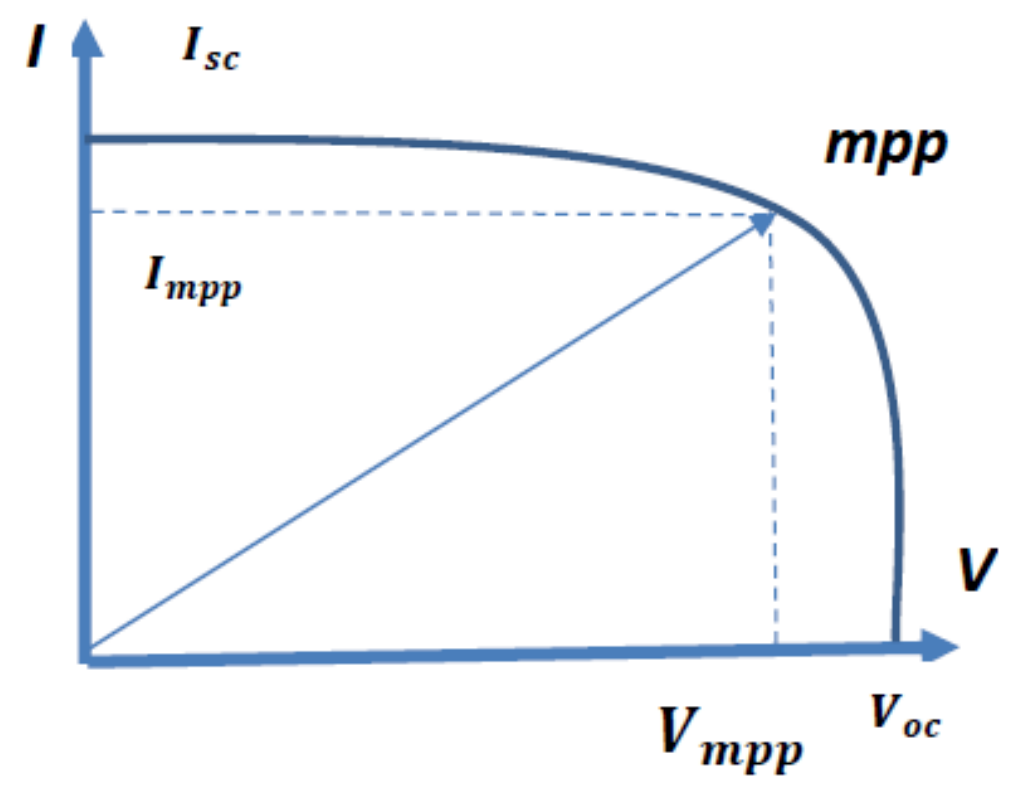

Figure 1. Load characteristics in solar cells [Authors own study].

In addition, it measures the reduced quality of a diode due to recombination and space-charges formation due to unbalanced transport.

Later advanced data analysis compared different algorithms to extract the parameters which contribute to the PV array model output [36]. The numerical Levenberg-Marquardt algorithm and metaheuristics such as Differential Evolution (DE), Genetic (GA), Particle Swarm Optimization (PSO), Ant Bee Colony (ABC) algorithms are used to extract and fit the parameters of two PV models, the five parameters model (5PM) and the Sandia Array Performance model (SAPM). The error analysis is made by two metrics, the Route Mean Square Error (RMSE) and the Normalized Mean Absolute Error (NMAE), where it is found that, in general, the metaheuristics depicted fewer errors [36].

Another research report conducted a detailed correlation coefficient analysis regarding PV output and environmental variables. It was noted that, when included in the model, the module characteristics, ambient temperature, air speed, perpendicular irradiance on the array, and relative humidity contributed to less error in the PV prediction of the maximum output [36].

It is worth mentioning that, from the aforementioned analysis of the relationship between the $\mathrm{I}-\mathrm{V}$ characteristics and the cell temperature, the fundamental energy gap in 
the different band levels and the irradiation has already been established as a nonlinear relationship [37], besides the impacts of defects and unstable materials behavior on cell degradation — which, in turn, limit the design's geometrical parameters [38,39] —or the Staebler Wronski (SW) defects [40]. In Figure 2, the loss mechanisms in a c-silicon cell are depicted [39].

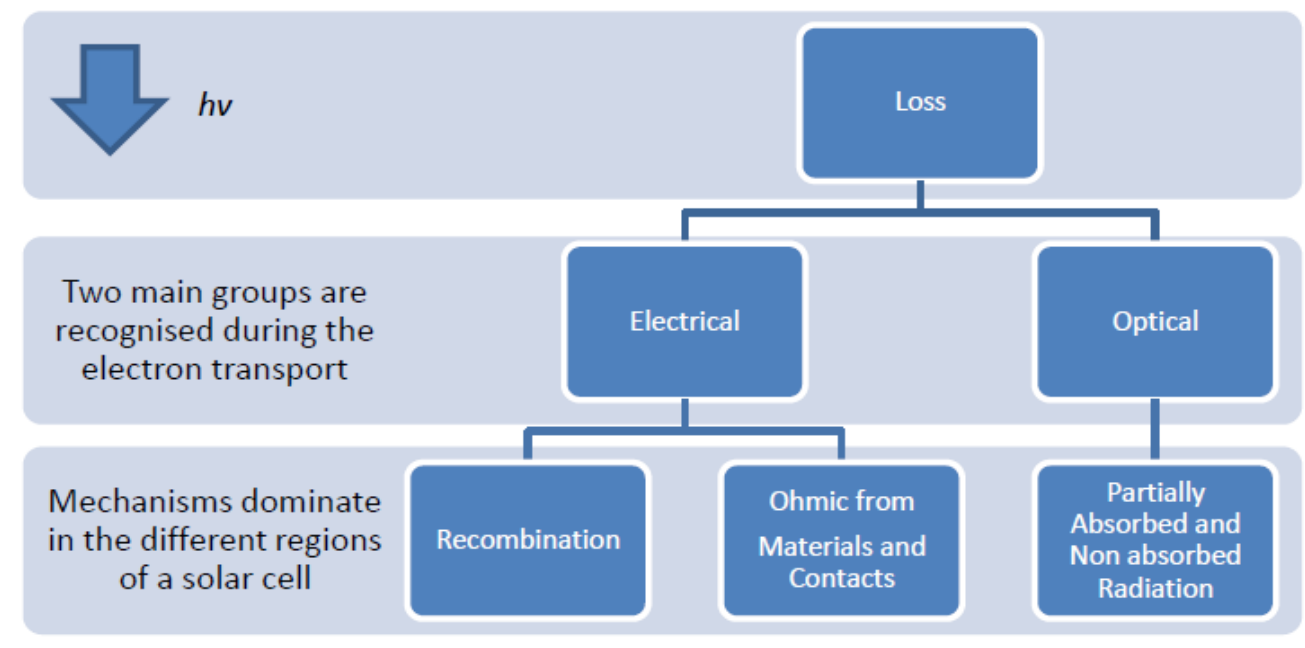

Figure 2. Main photon to charge loss mechanisms.

\section{Photovoltaic Cell Energy Conversion}

\subsection{Fundamental Aspects}

Photovoltaic solar to energy conversion is based on the electron behavior of semiconductors which originates from the existence of two electron energy bands: the valence and conduction bands. The energy difference between the bottom of conduction and the top of the valence band is the energy gap, $E_{g}$. It is well known that the incoming energy of a photon ( $h$ stands for Plank's constant and $v$ for frequency), $h v$, when is greater than $E_{g}$, is absorbed and may create bound pairs of electrons-holes, the excitons. This disruption of a covalent bond transfers electrons from the valence to conduction band, leaves a hole behind, changes the conductivity, and becomes the carrier of electricity. The doping of certain impurities within the material dominates different sites of donors and acceptors in the lattice, corresponding to positive and negative regions. Therefore, the diffusion of electron and holes develops a contact potential, about $1 \mathrm{~V}$ under room temperature and certain doping. The potential across the p-n junction is constant and the electric field is limited to a narrow transition region. The ability of the electrons to drift into that field immediately or with delay due to recombination depends on their distance from that field and other interactions. Thus, the separation of the excitons makes the electrons serve as an external current.

\subsection{Photogenerated Current}

The necessity of absorbing as many photons as possible obligates the use of materials with a low band gap, while the connections between cells are of utmost importance for the optimization of the solar energy yield. In PV systems, since the majority of photodiodes were exposed to photons within differentiated energy streams, the efficiency is prevailed by several mechanisms to exceed beyond certain values or approach the Shockley-Queissier (S-Q) limit [41]. The portion of the unabsorbed photons, the thermalization effect, and the time dependent recombination contribute to electricity conversion, with losses leading to the partial utilization of the spectrum and photon energy. These interactions are usually contradicted and affect the tradeoff for the critical properties of the solar cell design decisions.

Moreover, energy production is simultaneously happening with the fundamental principle of time micro-reversibility, namely that the solar photons from the sun are con- 
verted into electricity within solar cells but also reemitted as thermal radiation. The emitted radiation produced by the electro-hole excess energy in the cell is luminescent, which means that the electrochemical potential of photon differs by zero, obeying the modified Planck law, and the thermodynamic efficiency of a solar converter is limited by the Carnot efficiency between the working source (sun temperature at about $6000 \mathrm{~K}$ ) and the heat sink at the cell temperature [42].

\subsection{Recombination Limits}

The significance of the effective lifetime of the charge carriers to generate current and their dependance on the recombination processes has already been noted. There are three reasons for this association: (a) the doping level, (b) the irradiance of the cell, and (c) the nature and quality of the semiconductor. Accordingly, we recognize the following recombination processes which are interrelated with the abovementioned reasons: the surface density recombination, the Shockley-Read-Hall (SRH) recombination through undesirable light traps, the radiative recombination, and the Auger recombination-which has to do with the probability of a conduction band electron to transfer the excess energy to a valence band hole or to another conduction band electron. The latter denotes a three-particle process of the electron hole concentration under illumination and increases with the cube of the carrier concentration, making a great contribution as a limited open voltage $\left(V_{o c}\right)$ and efficiency factor, depending on the materials used. Typical mechanisms of recombination in solar cells are related to luminescence, SRH defects, SRH on impurities, Auger, and surface. In general, the total recombination rate, $\tau_{\text {total }}$, is related to the other ones, namely the radiation $\left(\tau_{\text {radiation }}\right)$, Auger $\left(\tau_{\text {Auger }}\right)$, and trapping $\left(\tau_{\text {trap }}\right)$ recombination by the following equation:

$$
\frac{1}{\tau_{\text {total }}}=\frac{1}{\tau_{\text {radiation }}}+\frac{1}{\tau_{\text {Auger }}}+\frac{1}{\tau_{\text {trap }}}
$$

For example, in crystalline silicon solar cells the Auger recombination dominates and the distribution is: Auger $82 \%$, radiative $9 \%$, SRH 7\% and surface $2 \%[43,44]$.

\subsubsection{Single Junction Cells}

In inorganics semiconductors, unlike organics, the Boltzmann energy, $k T$, ( $k$ is the Boltzmann's constant and $T$ the temperature) is much larger than the exciton binding energy atroom temperature and therefore the free charges are easily created while the material is excited. The increasing interest in the solar energy has led to the research and advanced alternatives to enhance the PV output. The inorganic semiconductors have been intensively investigated, and reached high efficiencies with the Tungsten Diselenide $\left(W_{S} e_{2}\right)$ absorbers, while there is further research to investigate the photonic crystals and the trapping mechanisms in certain silicon thin films, potentially beyond the Lambertian limits and conversion efficiency of $30 \%$, close to the S-Q limit $[45,46]$.

On the other hand, in the last decade the organic PVs have doubled in efficiency, reaching about $12 \%[47,48]$. The heterojunction architecture consists of a blend of electron donating (p-type) and electron accepting (n-type) organic semiconductors which drive photogenerated excitons, bound electro-hole pairs, separate free charges, and generate current.

Further developments are made with the dye sensitized cells, which exploit the challenges of liquid electrolytes with little transport between monolayers. The efficiency reached more than $13 \%$ and recently this concept also considered inorganic nanoparticles to act as sensitizers to replace the dye $[49,50]$.

An extraordinary incremental increase in efficiency (expected more than $20 \%$ ) came from the family of hybrid organic-inorganic materials of AMX3, namely perovskites $((\mathrm{CH} 3 \mathrm{NH} 3) \mathrm{PbI} 3)$, where the $\mathrm{A}$ stands for the inorganic site, $\mathrm{M}$ is the metal site, and $\mathrm{X}$ is a halogen [51,52].

Similar research is being made in the emerging field of nanotechnology, since the manipulation of solar cells nanostructures has become of utmost importance in terms of 
energy gap tunability, transport decoupling, and interfacial interactions which prove very different from the bulk material. The representatives of those structures, quantum dots, still remain at low levels, about $10 \%[53,54]$.

\subsubsection{Multi Cells Approaches}

The utilization of different band gap materials is a relatively new concept and depicts many challenges to be resolved due to the small efficiencies. Practically, the principles are based on the doping of large $E_{g}$ materials to formulate defect band in the gap $[55,56]$ or the creation of many separated states according to the quantum size effect $[57,58]$. The development of multi cell devices suppresses the unabsorbed photons fraction and the thermal effects but also increase the recombined carriers due to the photogeneration extraction.

\subsubsection{Spectrum Oriented Optimization}

Spectral manipulation PV systems include different strategies to maximize the overall solar radiation utilization of the incident broadband spectrum. They employ technologies shifting the solar spectrum to match more efficient wavelengths conversion, different bandgap materials in series or parallel, and splitting the spectrum in certain long and short-wave ranges to run efficiently with the combined thermal and photovoltaic processes [59].

The spectrum splitting systems are composed of two parts: the optical one to split the spectrum and concentrate the light and the other one to harvest the energy. With the creation of intermediate bands and recent technologies, potentially more than $50 \%$ efficiency may be obtained [60-62].

In a similar approach, cascade splitting by superposing is the simplest way to separate two photo diodes with different band-gaps and threshold. The problem to be overcome here is the interconnection of the diodes due to the non-illuminated face of the device which is metalized to act as a current collector, but also this makes it opaque and useless in a cascade configuration. Advance solutions are to build the used diodes from materials with the almost the same lattice constants but different band-gaps [63], tuning it by varying the stoichiometry of quaternary compounds. Another way is to filter concentrated sunlight through cells that absorb part of the energy (e.g., cobalt sulfate) while transmits the rest to underlying silicon diodes. Interference filters consist of a number of layers of materials with different refractive indices with band reflect and ripple regions.

Holographic concentrator operation is an attractive beam splitting technique and prepared to act as an extremely dispersive cylindrical lens. The far infrared is directed to a region to dissipate heat and to not affect the photodiode which has to operate at low temperatures to avoid loss of efficiency.

Different refractive and diffractive-spectral-beam-splitters techniques use (Table 1) holograms in common axis [64], non-uniform diffractive grafting or micro prism arrays as spectral beam splitters in multiple optical axis, and integrated diffractive/refractive arrays (Figure 3) in zig-zag axis [65].

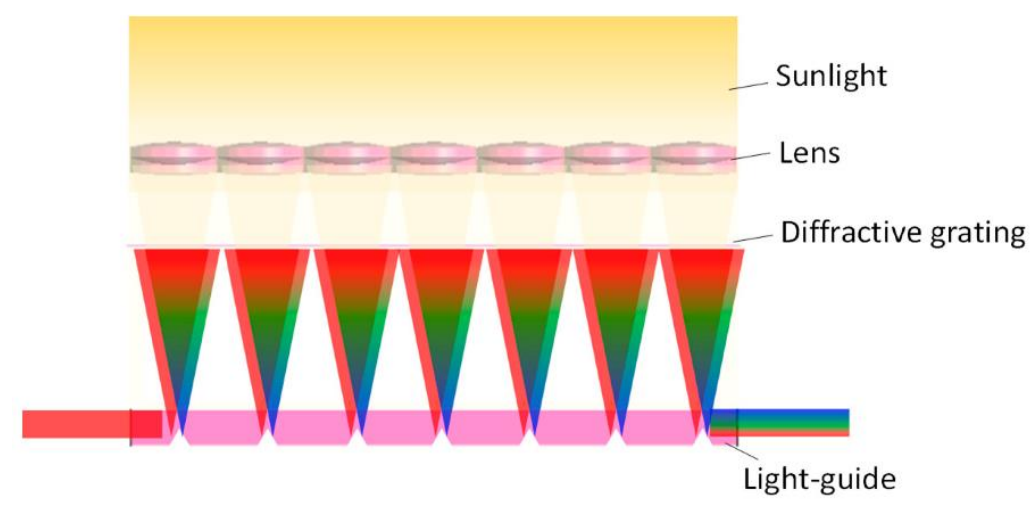

Figure 3. Spectral-beam splitting scheme in side absorption concentrated modules. Reproduced from [65], mdpi:2020. 
Table 1. Diffractive and spectral beam splitters (SBS) techniques. Reproduced from [65], mdpi:2020.

\begin{tabular}{|c|c|c|}
\hline Category & Characteristics of Technique & $\begin{array}{c}\text { Efficiency (Module or Systems in } \\
\text { Some Cases) }\end{array}$ \\
\hline Common axis & $\begin{array}{l}\text { SBS is formed by a reflective hologram and a } \\
\text { quadratic surface } \\
\text { A broadband receiver combined with an opening in } \\
\text { the center which includes another spectrally } \\
\text { selective receiver, all together mounted in a } \\
\text { above hologram }\end{array}$ & $\begin{array}{c}\mathrm{N} / \mathrm{A} \\
\\
21.4 \% \\
(\mathrm{PV} / \mathrm{T} \text { system })\end{array}$ \\
\hline Multiple optical axis & $\begin{array}{c}\text { A nonuniform diffractive-grating as a SBS } \\
\text { Micro-prism arrays as a SBS }\end{array}$ & $\begin{array}{c}34.7 \% \\
\text { (Dual-cell (InGaP/GaAs) system) } \\
\text { In: Indium, Ga: Gallium, As: Arsenide } \\
46.05 \% \\
\text { (Triple-cell (InGaP/GaAs/InGaAs) system) } \\
\text { P: Phosphorus }\end{array}$ \\
\hline Zig-zag axis & $\begin{array}{c}\text { Integrated diffractive / refractive optical element as } \\
\text { a SBS } \\
\text { A waveguide with engraved microstructures } \\
\text { beneath the SBS } \\
\text { Combined condenser, SBS and out-coupling adapter } \\
\text { in lenses, diffractive grating and a } \\
\text { light-guide, respectively }\end{array}$ & $\begin{array}{c}\leq 55 \% \text { (Module) } \\
34.8 \% \text { (module) } \\
29.5 \% \text { (Dual-cell silicon/germanium } \\
(\mathrm{Si} / \mathrm{Ge}) \text { system) }\end{array}$ \\
\hline
\end{tabular}

Carrier multiplication may occur when ionization of an atom by impact creates another exciton. This occurs with low efficiency, e.g., $<1 \%$, in bulk $\mathrm{Si}$, while it can proceed with nearly $100 \%$ efficiency if PbSe is in the form of nanocrystals of about $5 \mathrm{~nm}$ size. The excess photon energy is partitioned between the created electron and hole according to their respective masses $[66,67]$. The generation of multiple excitons before relaxation, and the very fast photo current collection or slowing down the relaxation are researched in bulk and quantum sized systems resulting in carrier multiplication (CM) and hot carrier transportation [68-70].

Another option is the design of specific optical nonlinear systems to manipulate as broad a spectrum as possible ranging from far infra-red into ultraviolet to reduce the thermal losses. The aforementioned concepts are enabled by some nano materials like graphene or carbon nanotubes (CNT) [71]. Broader light harvesting and increased current density have been successful due to the use of new sensitized dyes containing two carboxylic acids or two cyanoacrylic acids as linker groups to bind the metal oxide photo anode, instead of the conventional single linker group of the dye sensitized solar cell (DSSC) [72].

The thermophotovoltaic (TPV) systems use optical concentration devices to distinguish the heat generated from the photovoltaic conversion and generate more electricity. Potentially, they may provide high levels of efficiency, reporting a focus on the PV photothermal conversion to electricity and the thermal regulation of cell temperature (Figure 4). The basic parameters that are affected by the cell temperature are the open circuit voltage, $V_{o c}$, the short circuit current, $I_{s c}$, the fill factor, $F F$, and the energy conversion efficiency value ( $\eta$ ) [73].

A promising expansion of the PV concept concerns graphene-based thermionic and thermo radiative converters. The thermionic efficiency may improve the efficiency by including various irreversibility losses, such as space-charge effects and non-radiative recombination or suppression [68], mainly due to graphene's excellent conductivity, mobility, and linear band gap structure [69-72]. Moreover, the thermo radiative cell is able to produce electric current from the coldness of the outer space due to the exploitation of the negative illumination effect [73-80]. 


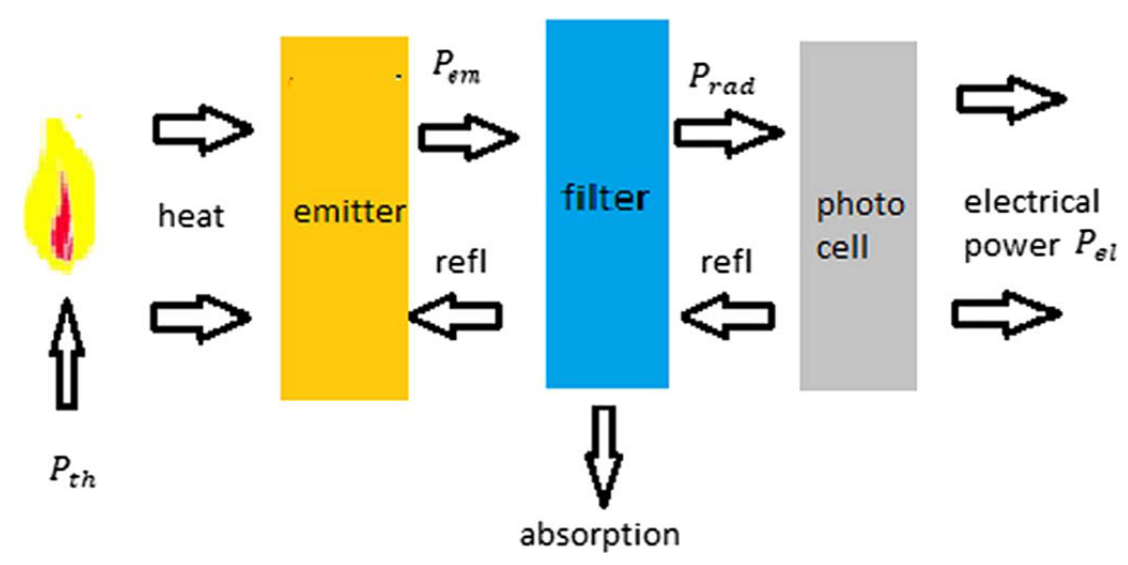

Figure 4. General structure of TPV system. Reproduced from [73], Oxford: 2020.

\subsubsection{Design Optimization}

The main performance parameters of the output are influenced by the physical and technological parameters of the design and manufacturing process, which, in turn, characterize the electrical, thermal, and optical properties on the operation. This optimization facilitates more efficient structures, regarding an integrated view of the sustainable development in PV fabrication. For example, in the most mature silicon-based PV industry, it is well known that the SW effect limits the architecture of the cells within certain boundaries (e.g., thickness in thin films) due to the hydrogen bonding configurations and the diffusion behavior under elevated and specified range of temperatures regarding the materials [40].

There are also reports of interesting interpretations which evolved the two side junctions, namely the npn structure, by adding a top pn junction in order to vertically absorb the light generated excitons and laterally collect them [81]. Moreover, the wafer-based silicon solar cells are challenged with the threshold between an expensive dense array of radial-orientated nanorods which are doped in pn junctions and the compensated cheap high-density defects and impurities of substrate absorbers, in order to optimize the demand. The former enhances the efficiency while the latter reduces the diffusion length of the carriers [81]. The main parameters that are analyzed refer to the dimensions (length, width, thickness), the doping quantity and quality, and the photon flux. The modelling displayed the causal effects of these parameters to the electrical characteristics (the open circuit voltage, short current density, the filling factor and the conversion efficiency), the optical performance, the quantum efficiency, and the spectral response.

\subsubsection{Nature-Inspired Solar to Energy Conversion}

In nature, the ideal photosynthesis efficiency differs, due to the debate on light energy definitions and also the irreversibility losses, such as the partially active light wavelength, probabilistic light trapping mechanisms, the recombination effects, the space-state, and the quantum considerations of the transitions. [82,83]. Yet, it has been reported that some molecular systems are optimized in photosynthetic processes and specific photon to charge transformations take place up to 1 conversion ratio within certain conditions. The intermediate functionality of the excitation energy transfer from the electronic state of the antenna pigments to the reaction centers has been observed to be accelerated by some microbial organisms playing the role of an active molecular pipeline, but also depicts quantum oscillations to be considered during the energy transfer [84-86]. The latter opened new pathways to the fabrication of artificial solar cells based on nature-inspired mimicking photosynthesis [87]. The competitive mechanisms between incoherence hopping and coherent tunneling are revealed as the dominant mechanism in the charge transfer. 


\section{Results and Discussion}

\subsection{Impacts of Material Properties and Fabrication Processes}

The main materials that impact on fabrication processes are linked to the intrinsic defects at the front and back interface of PV window layers. Such defects in these bulk materials can easily form photo-active alloys due to high defect density, thus restricting the current intensity of the device and determining the absorption of photons [88]. Subsequently, higher efficiency can be achieved according to the enhancement of the current intensity, necessitating control of fabrication methods of window layers. Besides, the increase in the carrier concentration results in challenging doping materials with different band gaps and wavelength absorption. These materials are designed with preferred band bending and reduced rear barrier heights of window layers, thus, avoiding the hole transportation resistance that limits the performance of Schottky junction $[89,90]$. It is noteworthy that, while the interaction of the window layer materials with the deposited and diffused doping atoms reduces the rear contact, it may also increase the potential barrier between them, restricting the photo generated charge carriers, e.g., Cadmium Telluride (CdT) cell technology, when doped with $\mathrm{Cu} / \mathrm{Au}$ (Copper/Gold), interacts with gold $(\mathrm{Au})$ atoms, while increasing the potential. Carbon nanotubes $(\mathrm{CNT})$, nanocomposites and nanocrystals with suitable valence band edges are also materials that can be used to overcome the contradicting effects [91-93]. Thermal evaporation, magnetron sputtering and chemical etching [94-98], electrostatic spray assisted vapor deposition [99], electrospinning, and annealing indium tin oxide (ITO) processes $[100,101]$ are preparation methods that have influential roles in the electrical and optical parameters. Enhanced operational characteristics of the examined devices, such as the short circuit current, Isc, the open circuit voltage, $V o c$ and the fill factor, $F F$, can relate surface/layer treatment with the photoconversion efficiency, $n$, via the output power derived, $P$, following equation:

$$
n=V_{o c} \times I_{s c} \times F F / P
$$

Besides, it can be noted that the minimization of charge recombination can increase the Fill Factor of the PV cells, thus increasing the efficiency of organic PV. Other ways of enhancing the charge transport can be implemented by the incorporation of cascaded atom number (Z) chalcogens, namely the small molecular donors (SMD), in the solubilizing side chains of the active layers which, in turn, can both promote the intermolecular interactions of atoms and further improve the connectivity. From an elementary viewpoint, oxygen $(\mathrm{O})$, sulfur (S), and Selenium (Se) atoms are capable of affecting the donor-acceptor phase aggregation. In particular, the $\mathrm{O}$ atoms promote tighter $\pi-\pi$ tighter stacking and the atoms of $\mathrm{S}$ and Se support a greater crystalline order in thin films [102]. Research efforts are also linked to manufacturing improvements, targeting the following:

- The smaller size heteroatoms, higher electronegativity of the heteroatoms, and larger moments of furan conjugated polymers or fullerene-based heterojunctions [103,104].

- Utilization of certain physical and chemicals treatments to manipulate the active layer absorption [105].

- Thermal stability of the inverted cell structure, thus improving the exciton transportation and efficient separation [106].

\subsection{Impact of Energy Harvesting on Energy Conversion Value}

When considering the impact energy harvesting on energy conversion value it is of utmost importance to note that the excess photon energy that becomes thermal losses accounts for more than half of the losses, leading towards possible energy harvesting exploitation. There are also reports of vivid interest in devices exploiting the unlimited dissipated thermal energy regarding solar to energy processes, resulting in manufacturing of small autonomous electronic devices with no need for power supply and maintenance, as well as increased conversion efficiency. Such a conversion efficiency increase can be 
attributed to the broadening of recycling and exploitation of thermal energy waste in many ways that commonly follow the principles of the thermoelectric conversion.

In a similar study [107] a power synthetic inductance circuit was created from the heat generated by the bearing, while other researches [108] proceeded to optimize the figure of merit of pyroelectric materials due to the improved properties of crystallinity, density, and the reduced permittivity derived from energy harvesting. The analysis supported advanced waste to energy applications with composite materials, due to the enhanced phonon transferring properties of the conductive networks.

In another recent study [109] a day-and-night combined operation of electricity and latent energy storage was investigated. Specifically, a Bismuth telluride (Bi2Te3) based thermoelectric generator (TEG), firstly, harvests the concentrated solar energy directed from Fresnel lens, while aluminum fins and mixed nanocomposite materials PCMs are functionally charging and discharging energy. Moreover, the creation of active layers of (QDs) and lithium chloride ( $\mathrm{LiCl}$ ) on top, being sandwiched between a substate and an aluminum contact, can develop a multi-step photon absorption mechanism that enabled the so-called mid gap states mechanism of the incorporated nanocrystals, allowing for harvesting of human body radiation [110]. Another critical research consideration is the exploitation of the second order phase transition above the Curie temperature from the ferromagnetic to paramagnetic phase to increase the cooling rate [111].

\subsection{Impacts of Light Harvesting on Photon to Charge Transfer}

The enhancement of light to current conversion, correspondingly, induces a wider range of power output, and may in the future yield over $35 \%$. Naturally occurring dipoledipole interactions between well oriented molecular excited states, generating quantum interference effects, may drive the future research. It is reported [112] that, in lasing, the quantum coherence breaks the balance in a cavity light trap, suppressing the absorption process, and, consequently, the emission dominates. The idea behind the reverse engineered phenomenon in the photovoltaic conversion is an optical pump device which could suppress the emission rate, hence, promoting the absorption rate, e.g., at ground level. In quantum mechanics, this can be achieved by adding a two-level relative transition amplitude which can coherently result in a destructive interference of the undesirable process, namely the emission [112]. Recent research on thin films, copper indium gallium diselenide (CIGS), towards the passivation of rear surface and light trapping in a nanocavity array showed the superior behavior of aluminum oxide (Al2O3) substrate and Voc and Jsc improvements about 10\% [113].

\section{Energy Transfer Interactions}

The interactive behavior of photons with solids comprises ionic and electronic oscillations and drives our focus on lattice vibrations. The dynamic response of the dielectric function on electromagnetic radiation can be comprehended by elementary oscillators, while yielding strong interaction of photons and transverse optical (TO) phonons with the accompanying large Reststrahl absorption in the infrared (IR) range [114]. The dispersion is described by a phonon-polariton, which is observed in inelastic scattering processes. In addition, Brillouin scattering at acoustic phonons along with Raman scattering at optical phonons can disseminate useful direct information about the spectrum and symmetry of vibrations in a semiconductor [115].

Charge and excitation energy transfer complexes are influenced by interactive mechanisms between the relative interactions of photon, phonon, electron, and excitons, to name a few, as in Figure 5, but the exact mechanisms have not yet been understood. Charge transfer is perturbatively understood by electron-electron interactions and the Dexter consideration of the exponentially decaying wave functions which is dominant within the field of some Angstroms. 


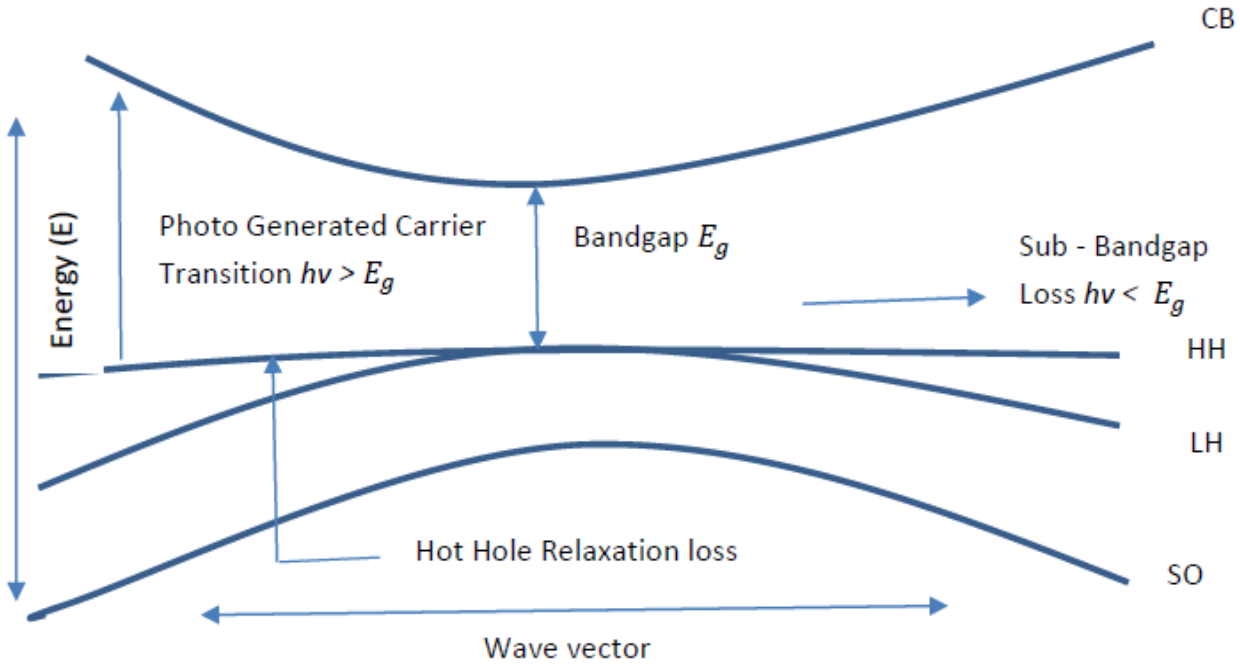

Figure 5. Photogenerated carrier transition, hot carrier relaxation, and sub-bandgap loss depicted in band gap GaAs (Gallium Arsenide). CB: The lowest conduction band., LH is the light hole valence, SO is the split-off hole valence band. [Authors own study] [116,117].

The interaction with lattice phonons leads to the conversion of excess kinetic energy into thermal energy. A hot electron may interact multiple times with longitudinal optical (LO) phonons and holes primarily interact with the transverse optical (TO) phonons. The latter relaxes faster than electrons due to the larger electronic density of states in the valence bands [116]. Moreover, the transversal and longitudinal photons intervene in excitation transfer and dipole-dipole interactions are mainly affected by the Coulombic participation beyond the Dexter domain, in the far field on some nanometers [117]. It is reported that efficiency strongly depends on the intrinsic coherence time of the coupled systems, the short and the long domain, which characterize the decoherent and coherent systems. However, it seems that the electro-electron interactions play a dominant role even in the excitation transfer [117], while, in another view, in organic solar cells, the electronphonon interactions revealed substantial influence on open circuit voltage and limited the efficiency performance [118]. Further analysis is needed to define the limitations between the quantum coherence and the incoherence hopping competition, which seems to be a main driver for the charge transfer efficiency, and the corresponding learning parameters for nature-adaptive optimization of the photosynthetic efficiency, from $1 \%$ to $100 \%$.

\section{Conclusions}

In the solar PV supply industry, the efficiency of the individual components of a PV system still remains at the cutting edge of technological interest and knowledge diffusion in niche markets. Among these technological challenges is PV-cell operating regulation, since it results in the efficient dissipation of thermal energy surplus. Furthermore, the concurring interaction between the PV system and its micro-environment leads to a capacity factor increase for the whole system while the PV components are more efficient and durable. Therefore, this study stressed the need for future research work towards module degradation, materials deterioration, and proper machinery engagement in producing PV systems at the desired cooling effect. The key findings are summarized here, and also define the limitations of our study:

- Key technology determinants on photon to charge efficiency are examined.

- Design, fabrication, and material impacts are presented.

- Efficient thermal energy dissipation and light harvesting improve performance.

- Nature-inspired photosynthetic optimization is discussed.

- Quantum dynamics are emphasized. 
The technological progress in efficiency of energy and materials stock and flows processes may play a key role, but also the analysis showed that there are multi-parameter long-run factors with positive or negative casualties to investigate further.

In summary, the electrical and optical parameters of the bulk PV cells are influenced both from the external microenvironment and the intrinsic fundamental principles of the energy gap difference between the two-level bands. A hierarchical taxonomy of the modelling and design critical parameters, fabrication and material impacts, recombination effects, and spectrum optimization technologies are analyzed. Light and energy harvesting issues need to be overcome, while nature-inspired mimicking and interpretation of photon to charge and excitation energy transfer are in an infant stage, leading towards a better understanding of artificial photosynthesis. Distinguishing between conventional diffusion behavior and the dynamics of the quantum walks on coherence and incoherence hopping excitations also opens a new route of research, due to competitive interactions with other fields, such as lasing, quantum thermal machines, or quantum supercomputing, to name a few.

Further research should include an integrated approach to quantifying the performance of PV systems to include the aforementioned wide spectrum of key-technology determinants, including photon to charge efficiency investigation, thermal regulation, exergy efficiency, irreversibility of losses, quantum coherence speedup limitations, as well as energy and light harvesting interpretation of natural photosynthetic processes.

Author Contributions: Conceptualization, V.K. and G.K.; methodology, V.K., G.K. and M.Z.; software, A.T.; validation, V.K., G.K., A.T. and M.Z.; formal analysis, V.K.; investigation, V.K and G.K. and M.Z.; resources, G.K.; data curation, V.K and A.T.; writing-original draft preparation, V.K.; writing-review and editing, V.K., G.K. and M.Z.; visualization, V.K.; supervision, V.K. and A.T.; project administration, V.K.; funding acquisition, V.K. All authors have read and agreed to the published version of the manuscript.

Funding: This research received no external funding.

Conflicts of Interest: The authors declare no conflict of interest.

\section{References}

1. Lin, B.; $\mathrm{Xu}, \mathrm{M}$. Regional differences on $\mathrm{CO}_{2}$ emission efficiency in metallurgical industry of China. Energy Policy 2018, 120, 302-311. [CrossRef]

2. Adom, P.K.; Kwakwa, P.A.; Amankwaa, A. The long-run effects of economic, demographic, and political indices on actual and potential $\mathrm{CO}_{2}$ emissions. J. Environ. Manag. 2018, 218, 516-526. [CrossRef] [PubMed]

3. Dulebenets, M.A. A comprehensive multi-objective optimization model for the vessel scheduling problem in liner shipping. Int. J. Prod. Econ. 2018, 196, 293-318. [CrossRef]

4. Andersson, F.N.; Opper, S.; Khalid, U. Are capitalists green? Firm ownership and provincial CO2 emissions in China. Energy Policy 2018, 123, 349-359. [CrossRef]

5. Abioye, O.F.; Dulebenets, M.A.; Pasha, J.; Kavoosi, M. A vessel schedule recovery problem at the liner shipping route with Emission Control Areas. Energies 2019, 12, 2380. [CrossRef]

6. Lo, P.L.; Martini, G.; Porta, F.; Scotti, D. The determinants of CO2 emissions of air transport passenger traffic: An analysis of Lombardy (Italy). Transp. Policy 2018, 91, 108-119. [CrossRef]

7. Wiginton, L.K. Quantifying rooftop solar photovoltaic potential for regional renewable energy policy. Comput. Environ. Urban. Syst. 2010, 34, 345-357. [CrossRef]

8. Ko, L. Evaluation of the development potential of rooftop solar photovoltaic in Taiwan. Renew. Energy 2015, 76, 582-595. [CrossRef]

9. Santos, I.P.; Ruther, R. The potential of building-integrated (BIPV) and building-applied photovoltaics (BAPV) in single-family, urban residences at low latitudes in Brazil. Energy Build. 2012, 50, 290-297. [CrossRef]

10. Zhao, X.; Zhang, X.; Riffat, S.B.; Su, Y. Theoretical study of the performance of a novel PV/e roof module for heat pump operation. Energy Convers. Manag. 2011, 52, 603-614. [CrossRef]

11. Ramos, A.; Chatzopoulou, M.A.; Guarracino, I.; Freeman, J.; Markides, C.N. Hybrid photovoltaic-thermal solar systems for combined heating, cooling and power provision in the urban environment. Energy Convers. Manag. 2017, 150, 838-850. [CrossRef]

12. Aravossis, K.G.; Kapsalis, V.C. Power Engineering: Advances and Challenges Part A. In Thermal Energy Storage Technologies; CRC Press: Boca Raton, FL, USA; Taylor and Francis Group: Abingdon, UK, 2018; Chapter 13; pp. 83-420. 
13. Qazi, S. Fixed Standalone PV Systems for Disaster Relief and Remote Areas. Chapter 5, In: Standalone Photovoltaic (PV) Systems for Disaster Relief and Remote Areas; Elsevier: Amsterdam, The Netherlands, 2017; Chapter 5; pp. 139-175. [CrossRef]

14. Murty, A.S.R.; Rajanish, Y.P.D. Enhanced energy harvesting and analysis of a high concentration photovoltaic / thermal system with support of cooling fluid and increased mass flow rates. Int. J. Eng. Technol. 2016, 8, 1077-1085.

15. Maranda, W. Analysis of self-consumption of energy from grid-connected photovoltaic system for various load scenarios with short-term buffering. SN Appl. Sci. 2019, 1, 406. [CrossRef]

16. Parida, A.; Choudhury, S.; Chatterjee, D. Optimized Solar PV Based Distributed Generation System Suitable for Cost-Effective Energy Supply. In Proceedings of the 9th Power India International Conference, Delhi, India, 28 February-1 March 2020; pp. 1-6. [CrossRef]

17. Ban-Weiss, G.; Wray, C.; Woody, W.; Ly, P.; Akbari, H.; Levinson, R. Electricity production and cooling energy savings from installation of a building-integrated photovoltaic roof on an office building. Energy Build. 2013, 56, 210-220. [CrossRef]

18. Dale, M.; Benson, S.M. Energy Balance of the Global Photovoltaic (PV) Industry-Is the PV Industry a Net Electricity Producer? Environ. Sci. Technol. 2013, 47, 3482-3489. [CrossRef] [PubMed]

19. Koo, C.; Hong, T.; Park, H.S.; Yun, G. Framework for the analysis of the potential of the rooftop photovoltaic system to achieve the net-zero energy solar buildings. Prog. Photovolt. Res. Appl. 2014, 22, 462-478. [CrossRef]

20. Ciulla, G.; Brano, V.L.; Di Dio, V.; Cipriani, G. A comparison of different one-diode models for the representation of I-V characteristic of a PV cell. Renew. Sustain. Energy Rev. 2014, 32, 684-696. [CrossRef]

21. Kilkis, S. A Rational Exergy Management Model for Curbing Building CO2 Emissions (LB-07-013), American Society of Heating, Refrigerating and Air-Conditioning Engineers (ASHRAE). Transactions 2007, 113, 76-86.

22. Onu, P.; Mbohwa, C. Advances in Solar Photovoltaic Grid Parity. In Proceedings of the 7th International Renewable and Sustainable Energy Conference (IRSEC), Agadir, Morocco, 27-30 November 2019; pp. 1-6. [CrossRef]

23. Drabiniok, E.; Neyer, A. Bionic micro porous evaporation foil for photovoltaic cell cooling. Microelectron. Eng. 2014, 119, 65-69. [CrossRef]

24. Ciulla, G.; Brano, V.L.; Cellura, M.; Franzotta, V.; Milone, D. A Finite Difference Model of a PV-PCM System. Energy Procedia 2012, 30, 198-206. [CrossRef]

25. Kichou, S.; Skandalos, N.; Wolf, P. Energy performance enhancement of a researchcentre based on solar potential analysis and energy management. Energy 2019, 183, 1195-1210. [CrossRef]

26. Park, J.; Kim, T.; Leigh, S.-B. Application of a phase-change material to improve the electrical performance of vertical-buildingadded photovoltaics considering the annual weather conditions. Solar Energy 2014, 105, 561-574. [CrossRef]

27. Browne, M.C.; Norton, B.; McCormack, S.J. Phase change materials for photovoltaic thermal management. Renew. Sustain. Energy Rev. 2015, 47, 762-782. [CrossRef]

28. Hasan, A.; McCormack, S.J.; Huang, M.J.; Norton, B. Characterization of phase change materials for thermal control of photovoltaics using Differential Scanning Calorimetry and Temperature History Method. Energy Convers. Manag. 2014, 81, 322-329. [CrossRef]

29. Atkin, P.; Farid, M.M. Improving the efficiency of photovoltaic cells using PCM infused graphite and aluminum fins. Solar Energy 2015, 114, 217-228. [CrossRef]

30. Chandrasekar, M.; Rajkumar, S.; Valavan, D. A review on the thermal regulation techniques for nonintegrated flat PV modules mounted on building top. Energy Build. 2015, 86, 692-697. [CrossRef]

31. Hasanuzzaman, M.; Malek, A.B.M.A.; Islam, M.M.; Pandey, A.K.; Rahim, N.A. Global advancement of cooling technologies for PV systems: A review. Solar Energy 2016, 137, 25-45. [CrossRef]

32. Cui, Y.; Wang, Y.; Huang, Q.; Wei, S. Effect of radiation and convection heat transfer on cooling performance of radiative panel. Renew. Energy 2016, 99, 10-17. [CrossRef]

33. Kandeal, A.W.; Thakur, A.M.; Elkadeem, M.R.; Elmorshedy, M.F.; Ullah, Z.; Sathyamurthy, R.; Sharshir, S.W. Photovoltaics performance improvement using different cooling methodologies: A State-of-Art Review. J. Clean. Prod. 2020, $273,122772$. [CrossRef]

34. Hrica, J.; Chatterjee, S.; TamizhMani, G. BAPV array: Thermal modeling and cooling effect of exhaust fan. In Proceedings of the 37th IEEE Photovoltaic Specialists Conference, Seattle, DC, USA, 19-24 June 2011; pp. 3144-3149. [CrossRef]

35. Kapsalis, V.C.; Karamanis, D. On the effect of roof added photovoltaics on building's energy performance. Energy Build. 2015, 108, 195-204. [CrossRef]

36. Kichou, S.; Silvestre, S.; Guglielminotti, L.; Mora-López, L.; Muñoz-Cerón, E. Comparison of two PV array models for the simulation of PV systems using five different algorithms for the parameters identification. Renew. Energy 2016, 99, 270-279. [CrossRef]

37. Kim, G.G.; Choi, J.H.; Park, S.Y.; Bhang, B.G.; Nam, W.J.; Cha, H.L.; Park, N.; Ahn, H.-K. Prediction Model for PV Performance With Correlation Analysis of Environmental Variables. IEEE J. Photovolt. 2019, 9, 832-841. [CrossRef]

38. Kichou, S.; Silvestre, S.; Nofuentes, G.; Torres-Ramírez, M.; Chouder, A.; Guasch, D. Characterization of degradation and evaluation of model parameters of amorphous silicon photovoltaic modules under outdoor long-term exposure. Energy 2016, 96, 231-241. [CrossRef]

39. Shen, L.; Li, Z.; Ma, T. Analysis of the power loss and quantification of the energy distribution in PV module. Appl. Energy 2020, 260, 114333. [CrossRef] 
40. Stradins, P. Staebler-Wronski defects: Creation efficiency, stability, and effect on a-Si:H solar cell degradation. In Proceedings of the 35th IEEE Photovoltaic Specialists Conference, Honolulu, HI, USA, 20-25 June 2010; pp. 142-145. [CrossRef]

41. Shockley, W.; Queisser, H. Detailed Balance Limit of Efficiency of p-n Junction Solar Cells. J. Appl. Phys. 1961, 32, 510-519. [CrossRef]

42. Luque, A. Will we exceed 50\% efficiency in photovoltaics. J. Appl. Phys. 2011, 110, 031301. [CrossRef]

43. Kerr, J.M.; Cuevas, A. General parameterization of Auger recombination in crystalline silicon. J. Appl. Phys. 2002, 91, 2473. [CrossRef]

44. Augusto, A.; Herasimenk, Y.S.; King, R.R.; Bowden, G.S.; Honsberg, C. Analysis of the recombination mechanisms of a silicon solar cell with low bandgap-voltage offset. J. Appl. Phys. 2017, 121, 205704. [CrossRef]

45. Hsieh, M.; Kaiser, A.; Bhattacharya, S.; Sajeev, J.; Lin, S.-Y. Experimental demonstration of broadband solar absorption beyond the lambertian limit in certain thin silicon photonic crystals. Sci. Rep. 2020, 10, 11857. [CrossRef] [PubMed]

46. Bhattacharya, S.; Sajeev, J. Photonic crystal light trapping: Beyond 30\% conversion efficiency for silicon photovoltaic. APL Photon. 2020, 5, 20902. [CrossRef]

47. Carle, J.E.; Krebs, F.C. Technological status of organic photovoltaics (opv). Sol. Energy Mater. Solar Cells 2013, 119, 309-310. [CrossRef]

48. Service, R.F. Outlook brightness for plastic solar cells. Science 2011, 293. [CrossRef]

49. Kamat, P.V. Quantum dot solar cells. Semiconductor nanocrystals as light harvesters. J. Phys. Chem. C 2008, 112, 18737-18753. [CrossRef]

50. Skandalos, N.; Karamanis, D. PV glazing technologies. Renew. Sustain. Energy Rev. 2015, 49, 306-322. [CrossRef]

51. McGehee, M.D. Materials Science: Fast-Truck solar cells. Nature 2013, 501, 323-325. [CrossRef]

52. Snaith, H.J. Perovskites: A emergence of new era for low cost, high efficiency solar cells. Phys. Chem. Lett. 2013, 4, 3623-3630. [CrossRef]

53. Bozyigit, D.; Volk, S.; Yarema, O.; Wood, V. Quantification of deep traps in nanocrystal solids, their electronic properties and the influence on device behavior. Nano Lett. 2013, 13, 5284-5288. [CrossRef] [PubMed]

54. Chuang, C.H.M.; Brown, P.R.; Bulovic, V.; Bawendi, M.G. Improved performance and stability in quantum dot solar cells through band alignment engineering. Nat. Mat. 2014, 13, 796-801. [CrossRef]

55. Wang, W.; Lin, A.S.; Phillips, J.D. Intermediate-band photovoltaic solar cell based on ZnTe: O. Appl. Phys. Lett. 2009, 95, 11103. [CrossRef]

56. Marti, A.; Tablero, C.; Antolin, E.; Luque, A.; Campion, R.; Novikov, S.; Foxon, C.T. Potential of mn doped ln1-xgaxn for implementing intermediate band solar cells. Sol. Energy Mater. Solar Cells 2009, 93, 641-644. [CrossRef]

57. Luque, A.; Marti, A.; Lopez, N.; Antolin, E.; Canovas, E.; Stanley, C.; Farmer, C.; Caballero, L.J.; Cuadra, L.; Balenzategui, J.L. Experimental analysis of the quasi-Fermi level split in quantum dot intermediate-band solar cells. Appl. Phys. Lett. 2005, 87, 83505. [CrossRef]

58. Shao, Q.; Balandin, A.; Fedoseyev, A.; Turowski, M. Intermediate-band solar cells based on quantum dot supracrystals. Appl. Phys. Lett. 2007, 91, 163503. [CrossRef]

59. Imenes, A.G.; Mills, D.R. Spectral beam splitting technology for increased conversion efficiency in solar concentrating systems: A review. Solar Energy Mater. Solar Cells 2004, 84, 19-69. [CrossRef]

60. Hossain, M.I.; Bousselham, A.; Alharbi, F.H. Optical concentration effects on conversion efficiency of a split-spectrum solar cell system. J. Phys. D Appl. Phys. 2014, 47, 075101. [CrossRef]

61. Abrams, Z.R.; Gharghi, M.; Niv, A.; Gladden, C.; Zhang, X. Theoretical efficiency of 3rd generation solar cells: Comparison between carrier multiplication and down-conversion. Sol. Energy Mater. Sol. Cells 2012, 99, 308-315. [CrossRef]

62. Bett, A.W.; Dimroth, F.; Stollwerck, G.; Sulima, O.V. III-V compounds for solar cell applications. Appl. Phys. A 1999, 69, 119-129. [CrossRef]

63. Meckler, M. Fixed Solar Concentrator-Collector-Satellite Receiver and Co-Generator. U.S. Patent 4 490-981, 1 January 1985.

64. Erim, M.N.; Erim, N.; Kurt, H. Spectral splitting for an InGaP/GaAs parallel junction solar cell. Appl. Opt. 2019, 58, 4265-4270. [CrossRef] [PubMed]

65. Wei, A.C.; Chang, W.J.; Sze, J.R. A Side-Absorption Concentrated Module with a Diffractive Optical Element as a Spectral-BeamSplitter for a Hybrid-Collecting Solar System. Energies 2020, 13, 192. [CrossRef]

66. Shaller, R.D.; Klimov, V.I. High efficiency carrier multiplication in PbSe nanocrystals: Implications for solar energy conversion. Phys. Rev. Lett. 2004, 92, 186601-186604. [CrossRef]

67. Takeda, Y.; Motohiro, T. Requisites to realize high conversion efficiency of solar cells utilizing carrier multiplication. Sol. Energy Mater. Sol. Cells 2010, 94, 1399-1405. [CrossRef]

68. Green, M.A. Third generation photovoltaics: Solar cells for 2020 and beyond. Phys. E Low Dimens. Syst. Nanostruct. 2002, 14, 65-70. [CrossRef]

69. Conibeer, G.; König, D.; Green, M.; Guillemoles, J. Slowing of carrier cooling in hot carrier solar cells. Thin Solid Film. 2008, 516, 6948-6953. [CrossRef]

70. Sun, D.; Aivazian, G.; Jones, A.M.; Ross, J.S.; Yao, W.; Cobden, D. Ultrafast hot-carrier-dominated photocurrent in graphene. Nat. Nanotechnol. 2012, 7, 114-118. [CrossRef] [PubMed] 
71. Gabor, N.M.; Song, J.C.; Ma, Q.; Nair, N.L.; Taychatanapat, T.; Watanabe, K.; Taniguchi, T.; Levitov, L.S.; Jarillo-Herrero, P. Hot carrier-assisted intrinsic photoresponse in grapheme. Science 2011, 334, 648-652. [CrossRef] [PubMed]

72. Holliman, J.P.; Mohsen, M.; Connell, A.; Kershaw, P.C.; Meza-Rojas, D.; Jones, W.E.; Geatches, D.; Sen, K.; Hsiao, Y.W. Double Linker Triphenylamine Dyes for Dye-Sensitized Solar Cells. Energies 2020, 13, 4637. [CrossRef]

73. Utlu, Z. Thermophotovoltaic applications in waste heat recovery systems: Example of GaSb cell. Int. J. Low Carbon Technol. 2020, 15, 277-286. [CrossRef]

74. Pidgeon, C.R.; Ciesle, C.M.; Murdin, B.N. Suppression of non-radiativeprocesses in semiconductor mid infrared emitters and detectors. Prog. Quantum Electron. 1997, 21, 361-419. [CrossRef]

75. Ang, Y.S.; Yang, H.Y.; Ang, L.K. Universal scaling laws in Schottky heterostructures based on two dimensional materials. Phys. Rev. Lett. 2018, 121, 56802. [CrossRef]

76. Xiao, G.; Zheng, G.; Qiu, M.; Li, Q.; Li, D.; Ni, M. Thermionic energy conversion for concentrating solar power. Appl. Energy 2017, 208, 1318-1342. [CrossRef]

77. Liao, T. Improved design of a photon enhanced thermionic energy converter. IEEE Electron. Device Lett. 2019, 40, 115-118. [CrossRef]

78. Santhanam, P.; Fan, S. Thermal-to-electric energy conversion by diodes under negative illumination. Phys. Rev. B 2016, 93, 161410. [CrossRef]

79. Ono, M.; Santhanam, P.; Li, W.; Zhao, B.; Fan, S. Experimental demonstration of energy harvesting from sky using the negative illumination effect of a semiconductor photodiode. Appl. Phys. Lett. 2014, 114, 161102. [CrossRef]

80. Salem, M.S.; Alzahrani, A.J.; Ramadan, R.A.; Alanazi, A.; Shaker, A.; Abouelatta, M.; Gontrand, C.; Elbanna, M.; Zekry, A. Physically Based Analytical Model of Heavily Doped Silicon Wafers Based Proposed Solar Cell Microstructure. IEEE Access 2020, 8, 138898-138906. [CrossRef]

81. Ross, R.T.; Hsiao, T.L. Limits on the yield of photochemical solar energy conversion. J. Appl. Phys. 1977, 48, 4783-4785. [CrossRef]

82. Bolton, R.; Hall, D.O. Photochemical conversion and storage of solar energy. Annu. Rev. Energy 1979, 4, 353-401. [CrossRef]

83. Engel, G.S.; Calhoun, T.R.; Read, E.L.; Ahn, T.K.; ManCal, T.; Cheng, Y.C.; Blankenship, R.E.; Fleming, G.R. Evidence for wavelike energy transfer through quantum coherence in photosynthetic systems. Nature 2007, 446, 782-786. [CrossRef]

84. Scholes, G.D. Quantum-coherent electronic energy transfer: Did nature think of it first? J. Phys. Chem. Lett. 2010, 1, 2-8. [CrossRef]

85. Vlaming, S.M.; Silbey, R.J. Correlated intermolecular coupling fluctuations in photosynthetic complexes. J. Chem. Phys. 2012, 136, 055102. [CrossRef] [PubMed]

86. Mohseni, M.; Shabani, A.; Lloyd, S.; Rabitz, H. Energy-scales convergence for optimal and robust quantum transport in photosynthetic complexes. J. Chem. Phys. 2014, 140, 035102. [CrossRef] [PubMed]

87. Creatore, C.; Parker, M.; Emmott, S.; Chin, A. Efficient biologically inspired photocell enhanced by delocalized quantum states. Phys. Rev. Lett. 2013, 111, 253601. [CrossRef] [PubMed]

88. Heo, J.H.; Im, S.H.; Noh, J.H.; Mandal, T.N.; Lim, C.S.; Chang, J.A.; Lee, Y.H.; Kim, H.; Sarkar, A.; Nazeeruddin, M.K.; et al. Efficient inorganic-organic hybrid heterojunction solar cells containing perovskite compound and polymeric hole conductors. Nat. Photonics 2013, 7, 486-491. [CrossRef]

89. Jeon, N.J.; Lee, J.; Noh, J.H.; Nazeeruddin, M.K.; Gratzel, M.; Seok, S.I. Efficient inorganic-organic hybrid perovskite solar cells based on pyrene arylamine derivatives as hole-transporting materials. J. Am. Chem. Soc. 2013, 135, 19087-19090. [CrossRef]

90. Li, G.; Govind, N.; Ratner, A.M.; Cramer, J.C.; Gagliardi, L. Influence of Coherent Tunneling and Incoherent Hopping on the Charge Transfer Mechanism in Linear Donor-ridge-Acceptor Systems. J. Phys. Chem. Lett. 2015, 6, 4889-4897. [CrossRef] [PubMed]

91. Bastola, E.; Alfadhili, F.K.; Phillips, A.B.; Heben, M.J.; Ellingson, R.J. Wet chemical etching of cadmium telluride photovoltaics for enhanced open-circuit voltage, fill factor, and power conversion efficiency. J. Mater. Res. 2019, 34, 3988-3997. [CrossRef]

92. Munshi, A.H.; Kephart, J.; Abbas, A.; Raguse, J.; Beaudry, J.N.; Barth, K.; Sites, J.; Walls, J.; Sampath, W. Polycrystalline CdSeTe/CdTe absorber cells with $28 \mathrm{~mA} / \mathrm{cm} 2$ short-circuit current. IEEE J. Photovolt. 2018, 8, 310. [CrossRef]

93. Paudel, N.R.; Yan, Y. Enhancing the photo-currents of CdTe thin-film solar cells in both short and long wavelength regions. Appl. Phys. Lett. 2014, 105, 183510. [CrossRef]

94. Li, J.; Diercks, D.R.; Ohno, T.R.; Warren, C.W.; Lonergan, M.C.; Beach, J.D.; Wolden, C.A. Controlled activation of ZnTe:Cu contacted CdTe solar cells using rapid thermal processing. Sol. Energy Mater. Sol. Cells 2015, 133, 208. [CrossRef]

95. Bastola, E.; Bhandari, K.P.; Subedi, I.; Podraza, N.J.; Ellingson, R.J. Structural, optical, and hole transport properties of earthabundant chalcopyrite (CuFeS2) nanocrystals. MRS Commun. 2018, 8, 970. [CrossRef]

96. Subedi, K.K.; Bastola, E.; Subedi, I.; Song, Z.; Bhandari, K.P.; Phillips, A.B.; Podraza, N.J.; Heben, M.J.; Ellingson, R.J. Nanocomposite (CuS)x(ZnS)1x thin film back contact for CdTe solar cells: Toward a bifacial device. Sol. Energy Mater. Sol. Cells 2018, $186,227$. [CrossRef]

97. Ochoa-Landin, R.; Vigil-Galan, O.; Vorobiev, Y.V.; Ramírez-Bon, R. Chemically-deposited Te layers improving the parameters of back contacts for CdTe solar cells. Sol. Energy 2009, 83, 134. [CrossRef]

98. Song, T.; Moore, A.; Sites, J.R. Te Layer to Reduce the CdTe Back-Contact Barrier. IEEE J. Photovolt. 2018, 8, 293-298. [CrossRef]

99. Watthage, S.C.; Phillips, A.B.; Liyanage, G.K.; Song, Z.; Gibbs, J.M.; Alfadhili, F.K.; Alkhayat, R.B.; Ahangharnejhad, R.H.; Almutawah, Z.S.; Bhandari, K.P. Selective Cd removal from CdTe for high-efficiency Te back-contact formation. IEEE J. Photovolt. 2018, 8, 1125. [CrossRef] 
100. Li, M.; Chang, F.; Li, C.; Xia, C.; Wang, T.; Wang, J.; Sun, M. CIS and CIGS thin films prepared by magnetron sputtering. Procedia Eng. 2012, 27, 12-19. [CrossRef]

101. Gulkowski, S.; Krawczak, E. RF/DC Magnetron Sputtering Deposition of Thin Layers for Solar Cell Fabrication. Coatings 2020, 10, 791. [CrossRef]

102. Wang, M.; Hossain, M.; Choy, K. Effect of Sodium Treatment on the Performance of Electrostatic Spray Assisted Vapour Deposited Copper-poor $\mathrm{Cu}(\mathrm{In}, \mathrm{Ga})(\mathrm{S}, \mathrm{Se}) 2$ solar cells. Sci. Rep. 2017, 7, 1-10. [CrossRef] [PubMed]

103. Wagner, J.; Gruber, M.; Hinderhofer, A.; Wilke, A.; Bröker, B.; Frisch, J.; Amsalem, P.; Vollmer, A.; Opitz, A.; Koch, N.; et al. High fill factor and open circuit voltage in organic photovoltaic cells with diindenoperylene as donor material. Adv. Funct. Mater. 2010, 20, 4295-4303. [CrossRef]

104. Du, J.; Fortney, A.; Washington, E.K.; Biewer, M.C.; Kowalewski, T.; Stefan, M.C. Benzo[1,2-b:4,5-b0]difuran and furan substituted diketopyrrolopyrrole alternating copolymer for organic photovoltaics with high fill factor. J. Mater. Chem. A 2017, 5, 15591. [CrossRef]

105. Galagan, Y.; Fledderus, H.; Gorter, H.; Mannetje, H.H.; Shanmugam, S.; Mandamparambil, R.; Bosman, J.; Rubingh, J.M.; Teunissen, J.P.; Salem, A.; et al. Roll-to-Roll Slot-Die Coated Organic Photovoltaic (OPV) Modules with High Geometrical Fill Factors. Energy Technol. 2015, 3, 834-842. [CrossRef]

106. Wang, Z.; Hong, Z.; Zhuang, T.; Chen, G.; Sasabe, H.; Yokoyama, D.; Kido, J. High fill factor and thermal stability of bilayer organic photovoltaic cells with an inverted structure. Appl. Phys. Lett. 2015, 106, 53305. [CrossRef]

107. Lubieniecki, M.; Uhl, T. Integration of Thermal Energy Harvesting in Semi-Active Piezoelectric Shunt-Damping Systems. J. Electron. Mater. 2015, 44, 341-347. [CrossRef]

108. Wang, Q.; Bowen, C.R.; Lei, W.; Zhang, H.; Xie, B.; Qiu, S.; Li, M.Y.; Jiang, S. Improved heat transfer for pyroelectric energy harvesting applications using a thermal conductive network of aluminum nitride in PMN-PMS-PZT ceramics. J. Mater. Chem. A 2018, 6, 5040-5051. [CrossRef]

109. Jeyashree, Y.; Sukhi, Y.; Vimala, J.A.; Lourdu, J.S.; Indirani, S. Concentrated solar thermal energy harvesting using Bi2Te3based thermoelectric generator. Mater. Sci. Semicond. Process. 2020, 107, 104782. [CrossRef]

110. Ghomian, T.; Kizilkaya, O.; Choi, J.W. Lead sulfide colloidal quantum dot photovoltaic cell for energy harvesting from human body thermal radiation. Appl. Energy 2018, 230, 761-768. [CrossRef]

111. Chun, J.; Song, H.; Kang, M.; Kang, H.; Kishore, R.A.; Priya, S. Thermo-Magneto-Electric Generator Arrays for Active Heat Recovery System. Sci. Rep. 2017, 7, 41383. [CrossRef]

112. Scully, M.O. Quantum photocell: Using quantum coherence to reduce radiative recombination and increase efficiency. Phys. Rev. Lett. 2010, 104, 207701. [CrossRef]

113. Dorfman, K.E.; Voronine, D.V.; Mukamel, S.; Scully, M.O. Photosynthetic reaction center as a quantum heat engine. Proc. Natl. Acad. Sci. USA 2010, 110, 2746-2751. [CrossRef]

114. Wang, Y.C.; Chen, C.W.; Su, T.Y.; Yang, T.Y.; Liu, W.W.; Cheng, F.; Wang, M.Z.; Chueh, Y.L. Design of suppressing optical and recombination losses in ultrathin CuInGaSe2 solar cells by Voronoi nanocavity arrays. Nano Energy 2020, 78, $2211-2855$. [CrossRef]

115. Boer, K.W.; Pohl, U.W. Photon-Phonon Interaction. In Semiconductor Physics; Springer: Cham, Switzerland, 2018 ; pp. 389-424.

116. Kirk, A.P. Advancing solar cell to the limit of energy cascading. In Proceedings of the 39th Photovoltaic Specialists Conference, Tampra Bay, FL, USA, 16-21 June 2013; pp. 782-787.

117. Schafer, C.; Ruggenthaller, M.; Appel, H.; Rubio, A. Modification of excitation and charge transfer in cavity quantumElectrodynamical chemistry. Proc. Natl. Acad. Sci. USA 2019, 116, 4883-4892. [CrossRef]

118. Panhans, M.; Hutsch, S.; Benduhn, J.; Schellhammer, K.S.; Nikolis, V.C.; Vangerven, T.; Vandewal, K.; Ortmann, F. Molecular vibrations reduce the maximum achievable photovoltage in organic solar cells. Nat. Commun. 2020, 11, 1488. [CrossRef] 